\title{
MIR1243 wt Allele
}

National Cancer Institute

\section{Source}

National Cancer Institute. MIR1243 wt Allele. NCI Thesaurus. Code C142771.

Human MIR1243 wild-type allele is located in the vicinity of 4q25 and is approximately 93 $\mathrm{kb}$ in length. This allele, which encodes MIR1243 pre-miRNA, is involved in the regulation of target mRNA translation. 